J. Clin. Chem. Clin. Biochem.

Vol. 20, 1982, pp. 567-570

\title{
Evaluation of Fluorescence Polarization Immunoassay for Serum Thyroxine Determination
}

\author{
By Makoto Muratsugu and Mikio Makino \\ Clinical Laboratory, Asahikawa Medical College Hospital, Nishikagura, A sahikawa, Japan
}

(Received November 16, 1981/February 16, 1982)

Summary: We have evaluated a fluorescence polarization immunoassay for thyroxine $\left(\mathrm{T}_{4}\right)$ using the polarization analyzer IBF-129.

Fluorescence polarization could be measured within 20 to 23 seconds after addition of fluorescein labeled thyroxine. The method exhibited excellent specificity and acceptable accuracy. The average intra- and inter-assay coefficients of variation were 4.8 and $12.3 \%$, respectively. The fluorescence polarization immunoassay was compared with a radioimmunoassay (RIA) using 96 clinical serum samples and gave a linear regression equation: $y=0.92 x+12.5$, with a correlation coefficient of $r=0.866(P<0.001)$.

\section{Prüfung eines Fluoreszenzpolarisations-Immunoassay für die Bestimmung von Thyroxin im Serum}

Zusammenfassung: Wir prüften einen Fluoreszenzpolarisations-Immunoassay für Thyroxin $\left(\mathrm{T}_{4}\right)$ mit dem PolarisationsAnalyser IBF-129.

Die Fluoreszenzpolarisation konnte innerhalb 20 bis 23 Sekunden nach Zugabe des Fluorescein-markierten Thyroxins gemessen werden. Die Methode zeigte eine hervorrragende Spezifität und annehmbare Richtigkeit. Die mittleren Variationskoeffizienten betrugen 4,8\% in der Serie und 12,3\% von Tag zu Tag. Der Fluoreszenzpolarisations-Immunoassay wurde mit einem Radioimmunoassay verglichen und ergab bei Verwendung von 96 klinischen Serumproben eine lineare Regressionsgleichung von $\mathrm{y}=0,92 \mathrm{x}+12,5$ mit einem Korrelationskoeffizienten von $\mathrm{r}=0,866(\mathrm{p}<0,001)$.

\section{Introduction}

The hormone thyroxine $\left(\mathrm{T}_{4}\right)$, secreted by the thyroid gland, has been measured by various methods. A competitive protein binding asșay (CPBA), first applied by Ekins (1) and further developed by Murphy \& Pattee (2), was the predominant method for thyroxine until the advent of a radioimmunoassay (RIA) for total thyroxine (3). In recent years, enżyme immunoasssay (EIA) (4) and homogeneous enzyme immunoassay (5) have also been used to determine thyroxine levels in serum. The radioimmunoassay and enzyme immunoassay (except for homogeneous enzyme immunoassay) require separation procedures for the determination of antigen or hapten in serum. The complex of antibody and isotope- or enzyme-labeled antigen or hapten must be separated from the free labeled component by an appropriate method. On the other hand, a fluorescence polarization method theoretically requires no separation procedures. The theory of the fluorescence polarization was developed by Perrin (6) and was extended through the work of Weber (7). Since the pioneering work of Dandliker et al. (8), the application of fluorescence polarization method to antigen-antibody reaction systems has been rapidly extended. For example, fluorescence polarization immunoassay of gentamicin (9) and phenytoin (10) have been reported by Smith et al. Human chorionic gonadotropin (11), neocarcinostatin and its antibody $(12)$, and cortisol $(13,14)$ have been measured by this method. Furthermore, instruments to measure only fluorescence polarization have been developed, but they are not yet used for routine work in the medical technology field.

In this paper, an evaluation of the thyroxine fluorescence polarization immunoassay is presented using a fluorescence polarization analyzer, IBF-129.

\section{Materials and Methods \\ Apparatus}

Fluorescence polarization was detected by a fluorescence polarization analyzer (JIMCO Model IBF-129, Sanko Junyaku Co., Ltd.). This apparatus is equipped with a lamp housing (tungsten lamp), excitation filter of $490 \mathrm{~nm}$, a cell housing, an analyzer which is rotated by a motor at $1800 \mathrm{~min}^{-1}$, an emission filter of $520 \mathrm{~nm}$, and a photomultiplier with an amplifier system connected to a digital printer. The arbitrary polarization, $P_{\text {arb., }}$ is 
presented as a multiple of around 1000 of the real polarization, $P$, defined by the equation

$$
P=\frac{I_{\prime \prime}-I_{\perp}}{I_{\prime \prime}+I_{\perp}}
$$

where $I_{\text {/, }}$ and $I_{\perp}$ represent the emission intensities polarized parallel and perpendicular to the direction of polarization of the exciting light, respectively. In an antigen-antibody reaction system, the specific antibody binds the antigen labeled with a fluorochrome, resulting in an increase of $P$. Upon addition of unlabeled antigen, bound labeled antigen will be displaced from the antibody and $P$ will decrease accordingly. The temperature of the cell housing is kept constant during the measurement with a Haake FK circulator (Haake Co., Ltd.).

\section{Reagents}

Fluorescein-labeled thyroxine, antiserum to thyroxine, standard thyroxine serum, and phosphate buffered saline containing polyethylene glycol were gifts from Sanko Junyaku Co., Ltd. in Tokyo. Methanol used for extraction of thyroxine from serum was reagent grade (Wako Junyaku Co., Ltd.).

The lyophilized fluorescein-labeled thyroxine, anti-thyroxine antibody (IgG fraction), and thyroxine standard serum were dissolved daily in the specified volume of distilled deionized water. The nominal concentration of the standards are 10,50 , 100,200 , and $400 \mu \mathrm{g} / 1$.

\section{Procedure}

Four hundred $\mu \mathrm{l}$ of methanol was added to $200 \mu \mathrm{l}$ of standard, pooled or sample serum in small siliconized test tubes. This mixture was vigorously stirred with a Vortex mixer and was allowed to stand for 5 minutes. The mixture was centrifuged for $10 \mathrm{~min}$ utes at $1000 \mathrm{~g}$. Fifty $\mu \mathrm{l}$ of the supernatant was added to $2 \mathrm{ml}$ of $1 / 15 \mathrm{~mol} / \mathrm{l}$ phosphate buffered saline containing $25 \mathrm{~g} / 1$ polyethylene glycol, $\mathrm{pH} 7.2$, and $50 \mu \mathrm{l}$ antibody to thyroxine was subsequently added. This mixture was vigorously stirred and incubated for 60 minutes at $25^{\circ} \mathrm{C}$ (unless otherwise specified). After incubation, $50 \mu \mathrm{l}$ of fluorescein-labeled thyroxine was added, the mixture was agitated for 20 to 23 seconds and the fluorescence polarization was immediately measured in the IBF-129. Measurements were performed at $25 \pm 0.1^{\circ} \mathrm{C}$.

\section{Preparation of charcoal treated serum}

For dilution of test sera or standards, charcoal treated serum was prepared by incubating $50 \mathrm{ml}$ of pooled serum $(84 \mu \mathrm{g} / \mathrm{l}$ thyroxine, RIA value) with $5 \mathrm{~g}$ of charcoal (Wako Junyaku Co., Ltd.) for 4 hours at room temperature. The charcoal was filtered off and the filtrate was divided into small aliquots which were stored at $-20^{\circ} \mathrm{C}$ until use. The concentration of thyroxine of this charcoal treated serum as determined by the radioimmunoassay was $14 \mu \mathrm{g} / \mathrm{l}$.

\section{Radioimmunoassay of thyroxine}

Serum thyroxine was measured simultaneously by use of TetraTab RIA kit (Nuclear-Medical Laboratories, Inc.) in Clinical Radiology, Asahikawa Medical College Hospital, Japan. Each kit contains an extractant $(0.025 \mathrm{~mol} / 1 \mathrm{HCl}),\left[{ }^{125}\right.$ I] thyroxine reagent ( $0.185 \mathrm{MBq}$ or less), anti thyroxine serum, precipitant (ammonium sulfate), diluent (barbital buffer), and standards $(10,60,120$, and $180 \mu \mathrm{g} / \mathrm{l}$ thyroxine $)$.

\section{Results}

\section{Time-course of $P_{\text {arb. and effect of incubation time }}$}

Figure 1 shows the time-course of $P_{\text {arb. }}$ and the effect of incubation time. The initial $\mathrm{P}_{\text {arb. }}$ obtained at 18,113 , and $209 \mu \mathrm{g} / 1$ thyroxine (RIA value) were around 400, 350 , and 300 , respectively. $P_{\text {arb. }}$ increases gradually with . time and reaches a plateau in about 5 6 hours (data

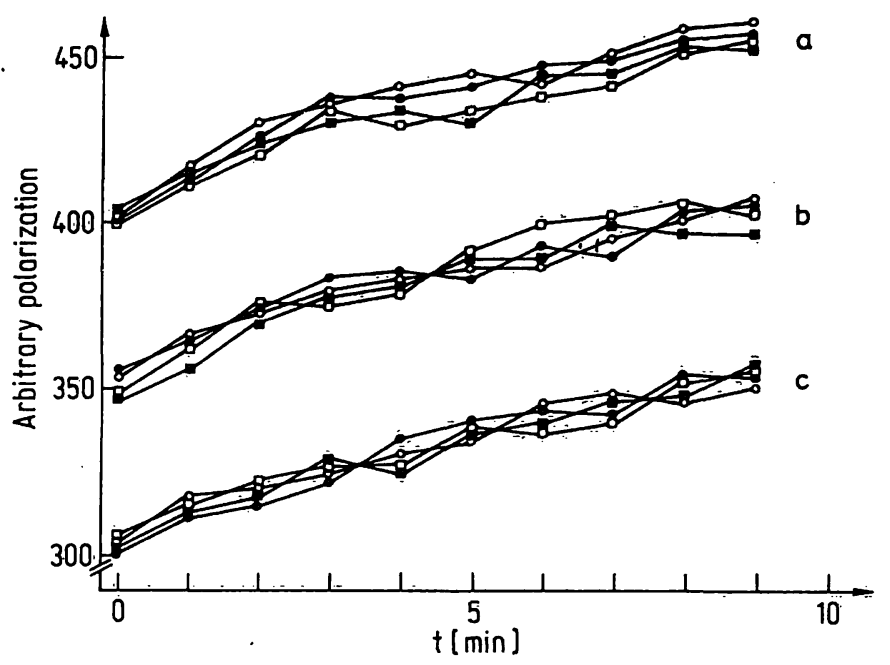

Fig. 1. Time-course of arbitrary polarization and effect of incubation time.

Incubation time: $\circ, 30 \mathrm{~min} ; \bullet, 60 \mathrm{~min} ; 0,90 \mathrm{~min}$; -, $120 \mathrm{~min}$.

Thyroxine concentrations: $\mathrm{a}, 18 \mu \mathrm{g} / \mathrm{l} ; \mathrm{b}, 113 \mu \mathrm{g} / \mathrm{l}$; c, $209 \mu \mathrm{g} / \mathrm{l}$.

not shown). The assay was incubated for $30,60,90$, and 120 minutes. As shown in figure 1 , the initial $P_{a r b}$. and the increase of $\mathrm{P}_{\text {arb. }}$ were not influenced by the incubation time for each level of thyroxine.

\section{Standard curve}

The standard curve is shown by the solid line in figure 2 . The points represent the mean value of $\overline{\mathrm{P}}_{\mathrm{arb}}$. and the bars two standard deviations. The concentration of thyroxine in the standard serum was measured by radioimmunoassay. Standard sera with intermediate levels were prepared by dilution of the commercially available, high thyroxine level standard serum with the charcoal treated serum.

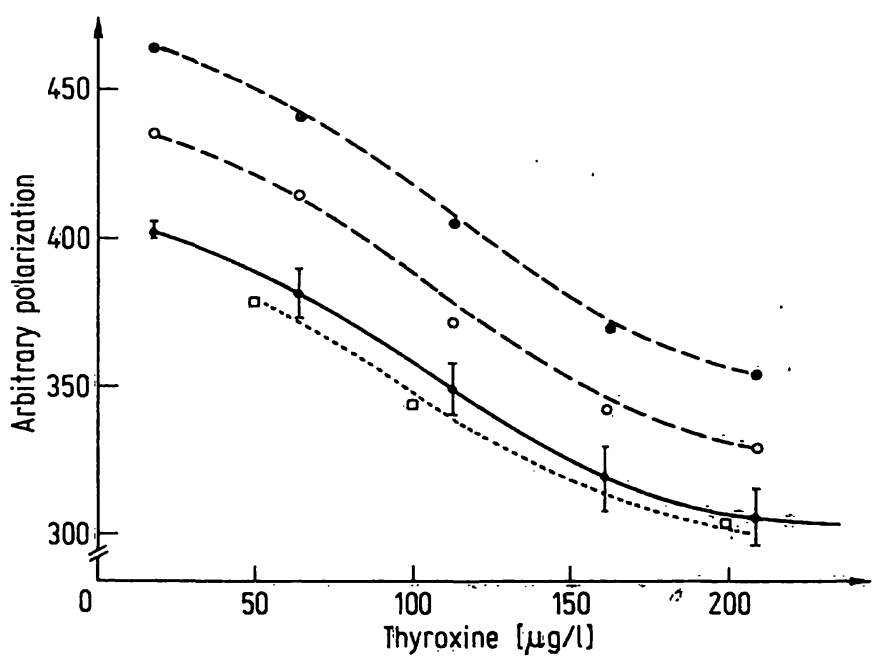

Fig. 2. Standard curve and dilution curve. Solid line is the - primary standard curve and dotted line (i) is the dilution curve. Broken lines are the standard curves obtained in $2(0)$ and $9 \min (\bullet)$. 
As mentioned above, $\mathrm{P}_{\mathrm{arb}}$. increases with time, so that the standard curves obtained in 2 or 9 minutes are parallel to the primary standard curve as shown by the broken lines in figure 2 . In this experiment the primary standard curve is used because the measurement is accomplished in a short time.

As is evident from the figure 2, the measurable range is from 18 to $209 \mu \mathrm{g} / 1$. For samples of serum having higher than $209 \mu \mathrm{g} / 1$ of thyroxine, dilution of the serum is required. The high thyroxine level serum was diluted with the charcoal treated serum and, as shown by the dotted line in figure 2, the dilution curve was parallel to the standard curve.

\section{Specificity of the method}

The specificity of the thyroxine antibody was examined by determining the cross reactivity of triiodothyronine $\left(3,5,3^{\prime}\right.$-triiodothyronine, $\left.T_{3}\right)$ with the thyroxine antibody (fig. 3 ). In these experiments triiodothyronine or thyroxine dissolved in methanol was used. When the concentration of thyroxine was $8 \mu \mathrm{g} / \mathrm{l}, \mathrm{P}_{\text {arb. was }} 322$, and the same value was obtained at $1000 \mu \mathrm{g} / 1$ triiodothyronine; indicating that the degree of cross reactivity is only $0.8 \%$ at this concentration.

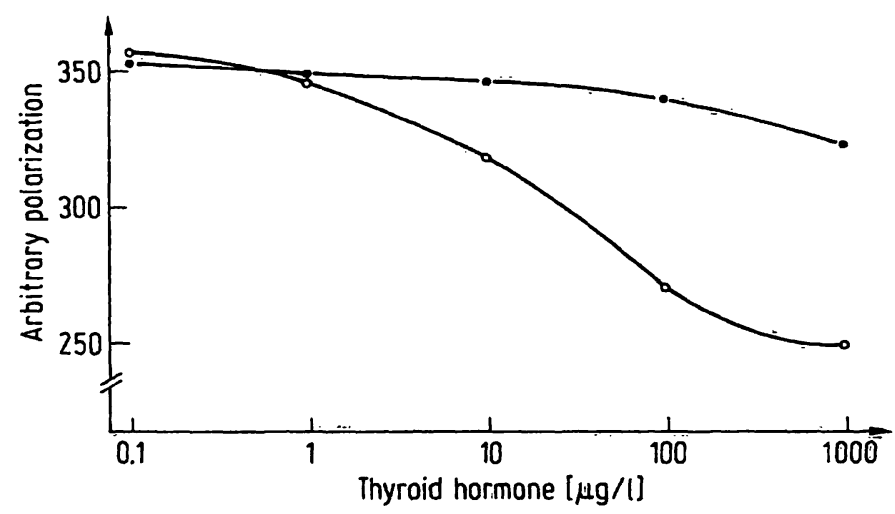

Fig. 3. Cross reactivity of triiodothyronine with thyroxine antibody. $\circ$, thyroxine; $\bullet$, triiod othyronine.

\section{Precision of the method}

The intra- and inter-assay reproducibility of the method was determined from the measurements of thyroxine concentration in pooled serum at three thyroxine levels. Ten determinations were made on the same day for each of the three pooled sera and the intra-assay mean thyroxine values for the low, intermediate, and high level pools are shown in table 1 . The average intra-assay coefficient of variation was $4.8 \%$. Six determinations were made on separate days and the inter-assay mean thyroxine values for the low, intermediate, and high level pools are also shown in table 1 . The average interassay coefficient of variation was $12.3 \%$.
Tab. 1. Intra- and inter-assay reproducibility of three thyroxine levels in sera.

\begin{tabular}{llccc}
\hline & $\begin{array}{l}\text { Thyroxine } \\
\text { levels }\end{array}$ & $\begin{array}{c}\text { Mean } \\
(\mu \mathrm{g} / \mathrm{l})\end{array}$ & $\begin{array}{l}\text { S.D.* } \\
(\mu \mathrm{g} / \mathrm{l})\end{array}$ & $\begin{array}{l}\text { C.V.** } \\
(\%)\end{array}$ \\
\hline Intra-assay & Low & 34 & 2.2 & 6.0 \\
$(\mathrm{n}=10)$ & Intermediate & 85 & 4.8 & 5.6 \\
& High & 174 & 4.7 & 2.7 \\
Inter-assay & Low & 36 & 4.5 & 12.4 \\
$(\mathrm{n}=6)$ & Intermediate & 76 & 9.6 & 12.6 \\
& High & 178 & 21 & 12.0 \\
\hline
\end{tabular}

* S.D.: standard deviation

** C.V.: coefficient of variation

\section{Accuracy of the method}

The accuracy of the method was examined through recovery studies, where the recovery of thyroxine added to charcoal treated serum was determined. The final concentration of added thyroxine was $106 \mu \mathrm{g} / \mathrm{l}$ and the average recovery for thyroxine was $104.5 \%$ (range: $95.2 \sim 109.4 \%, \mathrm{n}=5$ ).

\section{Correlation of methods}

Serum thyroxine values obtained from the fluorescence polarization method were compared with those obtained by radioimmunoassay. In figure 4 , the correlation between the two methods and the least squares line are shown. The correlation coefficient $(r)$ is 0.866 . The regression line is calculated as $y=0.92 x+12.5$, $y$ being the value obtained by fluorescence polarization method.

Twenty sera from the healthy students were analyzed. Thyroxine values $(59 \sim 99 \mu \mathrm{g} / 1)$ of these samples were in the normal range $(45 \sim 115 \mu \mathrm{g} / \mathrm{l})$ established for the radioimmunoassay of thyroxine (Tetra-Tab RIA kit).

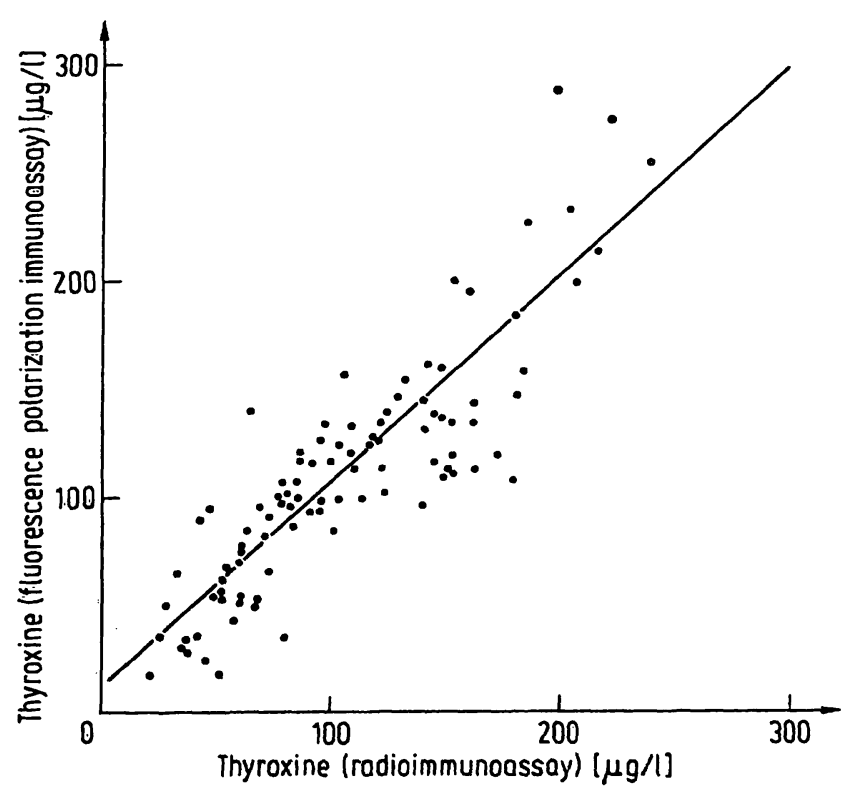

Fig. 4. Correlation between thyroxine values as measured by fluorescence polarization immunoassay and radioimmunoassay. $y=0.92 x+12.5 ; r=0.866(p<0.001), n=96$. 


\section{Discussion}

We evaluated the fluorescence polarization immunoassay for serum thyroxine level using the IBF-129.

$P_{a r b}$ values were not influenced by the incubation time, so that it is convenient for a large number of samples to be assayed at the same time. Thyroxine concentration was determined with a known amount of anti-thyroxine antibody, which first reacted with an unknown amount of thyroxine in samples, followed by addition of a definite amount of the fluorescein-labeled thyroxine. After addition of the labeled thyroxine, $P_{\text {arb }}$. was measured within 20 to 23 seconds, so that thyroxine content can be determined in a short time.

It may be concluded that specificity of the method was excellent (the degree of cross reactivity with triiodothyronine was $0.8 \%$ at a thyroxine concentration of $8 \mu \mathrm{g} / \mathrm{l})$. Triiodothyronine concentration in serum is less than $0.2 \%$ of the thyroxine concentration, so that the presence of triiodothyronine will not affect the assay in practice.

The average recovery of thyroxine added to the charcoal treated serum was $104.5 \%$, documenting the accuracy of the method.

Precision studies resulted in average intra- and inter-assay coefficients of variation for thyroxine of 4.8 and $12.3 \%$, respectively. The reproducibility was slightly inferior to that of the radioimmunoassay (Tetra-Tab RIA kit) used in the experiment (average intra- and inter-assay coefficients of variation of 3.6 and $6.7 \%$, respectively).

These values are acceptable at present, as it was reported that the average intra- and inter-assay coefficients of variation for cortisol obtained with use of IBF-129 were 14.3 and $17.1 \%$, respectively (13).

The method was compared with the radioimmunoassay. A correlation coefficient of 0.866 between the two methods was poor. We therefore determined the coefficient of determination, $\mathrm{r}^{2}$. This was 0.750 , which indicates that the proportion of the variation in the fluorescence polarization immunoassay associated with the variation in the radioimmunoassay is $75 \%$. Twenty five percent of the variation may be related to the inferior reproducibility of the fluorescence polarization immunoassay which is acceptable at present, as before. The fluorescence polarization immunoassay, however, does not require separation of anti-thyroxine antibody bound and free thyroxine as compared with radioimmunoassay. The method is non-isotopic and, therefore, can be performed in a usual laboratory without radiation hazards.

The fluorescence polarization immunoassay may be a more convenient technique for routine work, if the automation of the assay procedure is developed. At present, the assay for thyroxine requires the extraction procedure, so that automation is difficult. In the light of this problem, it is interesting to note that a direct assay system for cortisol has been developed by applying pretreatment of sêrum with sodium dodecyl sulfate which decomposes serum proteins (14). In the assay of thyroxine, however, the treatment with sodium dodecyl sulfate gave often abnormal high $\mathrm{P}_{\text {arb. values. Therefore, }}$ a different treatment must be found as a preliminary to automation; this is the subject of a future study. Further modification of the IBF-129 will be required for automation.

\section{Acknowledgement}

The authors are grateful to Sanko Junyaku Co., Ltd. for providiing the reagents, and to Messrs. Nishibu and Murakami in Clinical Radiology, Asahikawa Medical College Hospital in the determination of thyroxine concentration using by radioimmunoassay. A part of this research was supported by scientific research fund from the Ministry of Education, Japan.

\section{References}

1. Ekins, R. P. (1960) Clin. Chim. Acta 5, 453-459.

2. Murphy, B. E. P. \& Pattee, C. J. (1964) J. Clin. Endocrinol. Metab. 24, 187-196.

3. Chopra, I. J., Solomon, D. H. \& Ho, J. S. (1971) J. Clin. Endocrinol. Metab. 33, 865-868.

4. Monji, N., Malkus, H. \& Castro, A. (1978) Biochem. Biophys. Res. Commun. 85, 671-677.

5. Ullman, E. F., Blakemore, J., Leute, R. K., Eimstad, W. \& Jaklitsch, A. (1975) Clin. Chem. 21, 1011 (abstract).

6. Perrin, F. (1926) J. Phys. Radium. 7, 390-401.

7. Weber, G. (1952) Biochem. J. 51, 145-155.

8. Dandliker, W. B., Schapiro, H. C., Meduski, J. W., Alonson, R., Feigen, G. E. \& Hamrick, J. R., Jr. (1964) Immunochemistry $1,165-191$.

9. Watoson, R. A. A., Landon, J., Shaw, E. J. \& Smith, D. S. (1976) Clin. Chim. Acta 73, 51-55.

10. McGregor, A. R., Crookall-Greening, J. O., Landon, J. \& Smith, D. S. (1978) Clin. Chim. Acta 83, 161-166.

11. Urios, P., Cittanova, N. \& Jayle, M. F. (1978) FEBS Lett. 94, 54-58.

12. Maeda, H. (1978) Clin. Chem. 24, 2139-2144.

13. Kobayashi, Y., Amitani, K., Watanabe, F. \& Miyai, K. (1979) Clin. Chim. Acta 92, 241-247.

14. Kobayashi, Y., Miyai, K., Tsubota, N. \& Watañabe, F. (1979) Steroids $34,829-835$.

Dr. M. Muratsugu

Clinical Laboratory

Asahikawa Medical College Hospital

Nishikagura 4-5

Asahikawa 078-11, Japan 